\title{
Influence of Clay and Organic Matter of Rangeland Soils on Tebuthiuron Effectiveness
}

\author{
K.W. DUNCAN AND C.J. SCIFRES
}

\begin{abstract}
Phytotoxicity of tebuthiuron applied at $0.12,0.25$, or $0.5 \mathrm{ppm}$ to 10 different rangeland soils containing huisache in the greenhouse was inversely related with clay and organic matter contents. However, influences of soil properties were greatest at low herbicide dosages and could be masked by increasing tebuthiuron application rate. For example, tebuthiuron at 1 or 2 ppm killed the huisache after 287 days, regardless of soil, whereas 0.12 or 0.25 ppm killed huisache only when applied to soils with less than 15\% clay (these soils contained less than $2.5 \%$ organic matter). Potential for tebuthiuron phytotoxicity appears to be greatly diminished in solls containing more than $30 \%$ clay. Although the effects of organic matter were confounded with soil clay contents in this study, variations in clay content consistently accounted for a greater proportion of variation in huisache response than did organic matter content.
\end{abstract}

Pelleted herbicides possess several advantages compared to use of foliar-active sprays for range weed and brush control, especially reduced drift potential, negligible volatilization hazard, and a longer application season (Scifres 1980). Tebuthiuron [ $\mathrm{N}-(5-[5-$ [1,1-dimethylethyl]-1,3,4-thiadiazol-2-yl)-N,N'dimethylurea] is applied as an extruded pellet, and effectively controls a number of undesirable species in the South Texas mixed-brush complex (Scifres et al. 1979); blackjack oak (Quercus marilandica Muenchh.), post oak (Quercus stellata Wang.), and several associated species in east central Texas (Scifres et al. 1981); sand shinnery oak (Quercus havardii Rydb.) (Pettit and Jones 1978); creosotebush (Larrea divaricata Cav.) Jacoby et al. 1982); tarbush (Flourensia cernua DC.) (Ueckert et al. 1982); and other brush species.

Soil-active herbicides such as tebuthiuron depend on rainfall for transport into the root zone of the target species (Scifres 1980). The degree of longevity of huisache activity in the soil is regulated by its susceptibility to leaching, chemical degradation, decomposition by microbes, and/or adsorption onto the soil colloids (Kearney and Kaufman 1969). Since these processes reduce the amount of herbicide available for uptake by plants, an understanding of soilherbicide interactions is of practial importance to range resource managers, especially as it influences decisions concerning rate of herbicide required for weed and brush control effectiveness.

Numerous workers (Kearney and Kaufman 1969, Dubey and Freeman 1969, Hance 1965, Sherburne and Freed 1954, Upchurch 1958) have indicated organic matter to be the single most important soil characteristic in adsorption of substituted-area herbicides. Garcia and Gontarek (1976) reported tebuthiuron residues to be greatest in the surface $15 \mathrm{~cm}$ of soil 14 months after application to west Texas rangelands. They suggested that organic

\footnotetext{
Authors are former graduate research assistant and professor, the Texas Agricultural Experiment Station (Department of Range Science). Texas A\&M University, College Station, 77843. Duncan is presently research specialist, Elanco Products Company, Farmer's Branch, Tex. 75234. The efforts of Julia Scifres in manuscript typing and preparation are greatly appreciated. Approved by the Director, Texas Agricultural Experiment Station as TA-17697.

Received for publication May 20, 1982.
}

matter in the surface layer adsorbed tebuthiuron, thereby preventing its leaching. Chang and Stritzke (1977) also reported that soil mobility of tebuthiuron was greater in soils with low organic matter and clay contents. They found that $40 \%$ of the tebuthiuron was adsorbed when applied to soil with $4.8 \%$ organic matter. Tebuthiuron residues at $30 \mathrm{~cm}$ deep persisted for more than 2 years in Axtell fine sandy loam (organic matter ranged from 0.1 to $4.4 \%$, depending on depth) (Bovey et al. 1982).

However, Harris and and Warren (1964) indicated that organic matter may be responsible for more adsorption of herbicides by some soils and clay more important in others, since soil compositions vary so greatly. Sheets (1958) and Geissbuhler et al. (1963) reported that varying amounts and types of clay minerals could influence adsorption of phenylurea herbicides, particularly in soils with relatively low organic matter content. There has been little definitive research as to the differences in brush control levels that may be attributed to variations in soil organic matter and clay contents after the application of tebuthiuron on rangeland. Moreover, most related research has utilized crops as the assay species (Bovey et al. 1982). This study was designed to investigate the influence of clay and organic matter contents of rangeland soils on the phytotoxicity of tebuthiuron to huisache (Acacia farnesiana L.).

\section{Materials and Methods}

Effects of soil characteristics on tebuthiuron phytotoxicity were investigated in the greenhouse with 10 different rangeland soils. Soil samples were collected from the surface $15 \mathrm{~cm}$ at sites in San Patricio, Robertson, and Brazos counties, Texas (Table 1). Soil texture by the hydrometer method (Black 1965, Day 1956), organic matter content by acid digestion and titration (Mortensen 1965), and $\mathrm{pH}$ of a 1:1 slurry were determined on triplicate subsamples from each collection.

The soils were air dried, screened through 2-mm mesh, and placed in plastic pots $(1,000 \mathrm{~g} / \mathrm{pot})$. Eight to 10 huisache seeds were planted approximately $1 \mathrm{~cm}$ deep in 30 pots of each soil series. Tebuthiuron was applied to the soil when the seedlings were 15 to $20 \mathrm{~cm}$ tall (45 days after planting). Adequate amounts of a tebuthiuron stock solution ( 1 part per thousand active ingredient of the $80 \%$ wettable powder) was pipetted onto the soil surface to achieve $0,0.12,0.25,0.5,1$, or $2 \mathrm{ppm}$ (wt/wt). Each treatment was replicated 5 times with each soil series. Treatments were arranged in a completely random design, and the experiment was conducted twice.

The huisache plants were watered with surface applications of distilled water. Cups were placed beneath each pot to capture overlow and leachate which was returned to the soil surfaces.

Defoliation of huisache was rated on a scale of 0 to $10(0=$ no defoliation; $10=$ complete defoliation) at 63,97 , and 165 days following tebuthiuron application. Numbers of dead huisache plants were counted at 232 and 297 days following herbicide application. 
Table 1. Organic matter content (\%), pH (1:1 slurry), textural components (\%), and textural classes of various soils used in experiments to evaluate infuence of soil properties on response of huisache to tebuthiuron.

\begin{tabular}{|c|c|c|c|c|c|c|c|}
\hline \multicolumn{2}{|l|}{ Soil } & \multirow[b]{2}{*}{ Textural class } & \multicolumn{3}{|c|}{ Textural components (\%) } & \multirow{2}{*}{$\begin{array}{c}\begin{array}{c}\text { Organic } \\
\text { matter } \\
(\%)\end{array} \\
\end{array}$} & \multirow[b]{2}{*}{ pH } \\
\hline Subgroup & Series & & Sand & Silt & Clay & & \\
\hline Udic Pellustert & Victoria & Clay & 19 & 19 & 62 & 1.6 & 7.3 \\
\hline Vertic Haplaquoll & Aransas & Clay & 19 & 21 & 60 & 2.1 & 7.1 \\
\hline Cumulic Haplustoll & Odem & Fine sandy loam & 77 & 12 & 11 & 1.3 & 7.4 \\
\hline Typic Ochraqualf & Orelia & Sandy clay loam & 17 & 50 & 33 & 5.7 & 5.7 \\
\hline Aquic Haplustalf & Delfina & Loamy fine sand & 84 & 12 & 4 & 0.9 & 6.0 \\
\hline Udertic Paleustalfs & Lufkin & Fine sandy loam & 76 & 12 & 12 & 1.0 & 7.2 \\
\hline Udertic Paleustalfs & Axtell & Sandy loam & 61 & 25 & 14 & 1.8 & 5.8 \\
\hline Udertic Paleustalf & Tabor & Sandy loam & 63 & 30 & 7 & 1.0 & 5.4 \\
\hline Vertic Argiustoll & Laparita & Sandy loam & 61 & 33 & 6 & 2.0 & 5.6 \\
\hline Alluvium & - & Loamy sand & 78 & 14 & 8 & 1.0 & 7.2 \\
\hline
\end{tabular}

Combined data from the experiments were analyzed using stepwise multiple regression analysis with defoliation or mortality response as the dependent variable and percentage clay, organic matter, and tebuthiuron rate as the independent variables. The relationship between bioassay response and the independent variables were evaluated based on the functional relationship, $\hat{Y}=a+b_{1}\left(\log X_{1}+1\right)+b_{2} \times X_{2}+b_{3} X_{3}$ where $\hat{Y}=$ defoliation rating or $\%$ mortality, $X_{1}=$ herbicide rate, $X_{2}=\%$ organic matter, and $X_{3}=\%$ clay. Data from each evaluation date were also used to develop simple regression equations for each herbicide rate using huisache response as the dependent variable and \% clay or \% organic matter content of the soils as the independent variable. The relationships between huisache response and the soil characteristics within herbicide concentrations were evaluated based on the functional relationship, $\hat{Y}=a+b(\log X)$ where $\hat{Y}=$ defoliation rating or $\%$ mortality and $X=\%$ clay or $\%$ organic matter. Differences in bvalues (slopes) among the simple regression equations (among herbicide concentrations) were evaluated with $t$-tests $(\propto \leq .05)$.

\section{Results and Discussion}

Soil textures varied from loamy sand to clay (Table 1). Clay contents ranged from $4 \%$ (Delfina loamy fine sand) to $62 \%$ (Victoria clay), and organic matter contents varied from $0.9 \%$ (Delfina loamy fine sand) to $5.7 \%$ (Orelia sandy clay loam). The soils were moderately alkaline to acidic.

Since huisache response to varying tebuthiuron concentrations as influenced by soil characteristics were similar within evaluation dates between experiments, data were pooled for presentation. Only defoliation responses at 63 days after tebuthiuron application and percentage mortality after 287 days will be presented since relative huisache response among soils was the same, regardless of evaluation date.

Rate of herbicide application (log[ppmw+1]) accounted for more variation in huisache defoliation after 63 days $\left(r^{2}=0.45\right)$ than did varying clay or organic matter contents. Including soil clay contents with herbicide rate resulted in the best two variable prediction equation, and accounted for $58 \%$ of the variation in huisache defoliation rating. The three variable equation, defoliation rating $=2.67+6.41 \log$ (herbicide rate +1$)-0.42(\%$ organic matter) -0.05 (\% clay) accounted for $61 \%$ of the variation in huisache defoliation after 63 days. Addition of soil $\mathrm{pH}$ to the prediction equation did not account for additional variation in percentage huisache defoliation, compared to that attributed to the best three variable model.

Although clay content and herbicide rate resulted in the best two variable model, organic matter content was associated with a greater regression coefficient than was clay content in the best three variable model. This indicates that organic matter can be expected to become increasingly important relative to tebuthiuron phytotoxicity in soils as clay content declines.

The influence of clay content on variation in huisache defoliation rating within a herbicide rate was greater than was the effect of organic matter. The impact of clay content on huisache defoliation at 63 days after tebuthiuron application was best expressed where $0.5,1$ or $2 \mathrm{ppm}$ had been applied (Figure 1). Tebuthiuron applied at $0.12 \mathrm{ppm}$ defoliated the huisache only when applied to soils with relatively low clay and organic matter contents.

Herbicide rate, soil clay content, and organic matter content influenced percentage of the huisache population killed at 287 days after tebuthiuron application in the same manner as discussed for defoliation after 63 days. This relationship was best expressed as, $\%$ mortality $=45.63+84.69 \log ($ herbicide rate +1$)-5.32(\%$

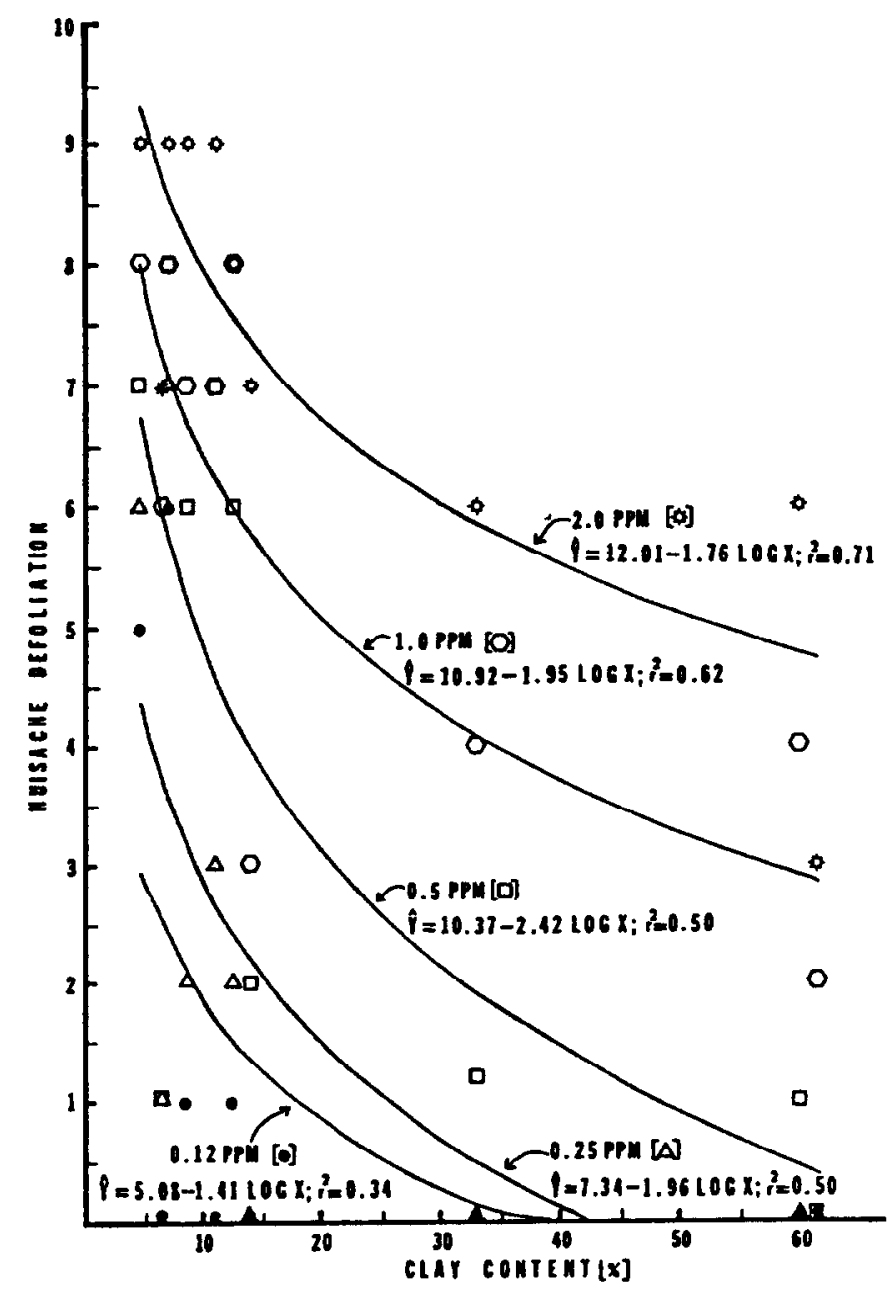

Fig. 1. Relationships of change in huisache defoliation $(0=$ no defoliation, $10=$ complete defoliation) with change in soil clay content (\%) at 63 days following application of various rates (ppmw) of tebuthiuron in a greenhouse. 
organic matter) $-0.49(\%$ clay $)$ with $r^{2}=0.51$. Herbicide rate may mask the influence of soil properties as evidenced by $100 \%$ mortality of huisache in pots treated with 1 or $2 \mathrm{ppm}$ of tebuthiuron, regardless of soil. However,the response curve where $0.5 \mathrm{ppm}$ of tebuthiuron was applied clearly indicated the importance of soil clay content in regulating availability of the herbicide (Figure 2). Also, substantial huisache mortality resulted when tebuthiuron was applied at 0.12 or $0.25 \mathrm{ppmw}$ to soils with less than $15 \%$ clay and $2.5 \%$ organic matter.

\section{Conclusions}

The influence of soil organic matter and clay contents were necessarily confounded in this study. Also, care must be exercised in extrapolation results from greenhouse experiments to field conditions since the potted plants were constantly exposed to the herbicide (no removal by leaching). However, the following relationships are important relative to use of tebuthiuron for brush control:

1). The singlemost important variable regulating response of a susceptible species to tebuthiuron is application rate. The negative influences of soil organic matter and clay contents on tebuthiuron activity may bc overcome by increasing the rate of application.

2). Soil clay content is the most important variable regulating response of susceptible species (assuming adequate rainfall for moving the herbicide into the soil solution) within a tebuthiuron application rate. This factor should be given special consideration, especially when the application rate is marginal relative to innate susceptibility of the target brush species, when making application decisions.

3). Although soil organic matter influences availability of tebuthiuron for uptake by plants, organic matter contents of many rangeland soils are not great enough to exert significant influence on ultimate control levels.

It is emphasized that these experiments were conducted under optimum soil water conditions and with one species. Timeliness and extent of rainfall and susceptibility of the target species ultimately determine whether the influences of clay and organic matter contents are exerted on tebuthiuron effectiveness.

\section{Literature Cited}

Black, G.R. 1965. Particle density. p. 371-373. In: C.A. Black (Ed.), Methods of Soil Analysis. Amer. Soc. Agron., Inc., Madison, Wis.

Bovey, R.W., R.E. Meyer, and H. Hein, Jr. 1982. Soil persistence of tebuthiuron in the claypen resource area of Texas. Weed Sci. 30:140-144.

Chang, S.S., and J.F. Stritzke. 1977. Sorption, movement and dissipation of tebuthiuron in soils. Weed Sci. 25:184-187.

Day, P.R. 1956. Report of the committee on physical analysis. Soil Sci. Soc. Amer. Proc. 21:662.

Dubey, H.D., and J.F. Freeman. 1969. Bioassay of diphenamid and linuron in soils. Bot. Gaz. 124:338-392.

Garcia, J.D., and B.D. Gontarek. 1976. Residues of the herbicide EL-103 in west Texas rangeland 14 months after application. Noxious Brush and Weed Res. Highlights, Texas Tech Univ., Lubbock. 6:10.

Geissbuhler, H., G. Haselback, and H. Aebi. 1963. The fate of N'-(chlorophenoxy)-phenyl-N,N-dimethylurea (C-1983) in soils and plants. Weed Res. 3:140-153.

Hance, R.J. 1965. Observations on the relationship between the absorption of diuron and the nature of absorbent. Weed Res. 5:108-114.

Harris, C.I., and G.F. Warren. 1964. Absorption and desorption of herbicides by soil. Weeds $12: 120-126$.

Jacoby, P.W., D.N. Ueckert, and F.S. Hartmann. 1982. Control creosotebush (Larrea tridentata) with pelleted tebuthiuron in western Texas. Weed Sci. (In press).

Kearney, P.C., and D.D. Kaufman. (Ed.). 1969. Degradation of herbicides. Marcel Dekker, Inc., New York. 79-11.

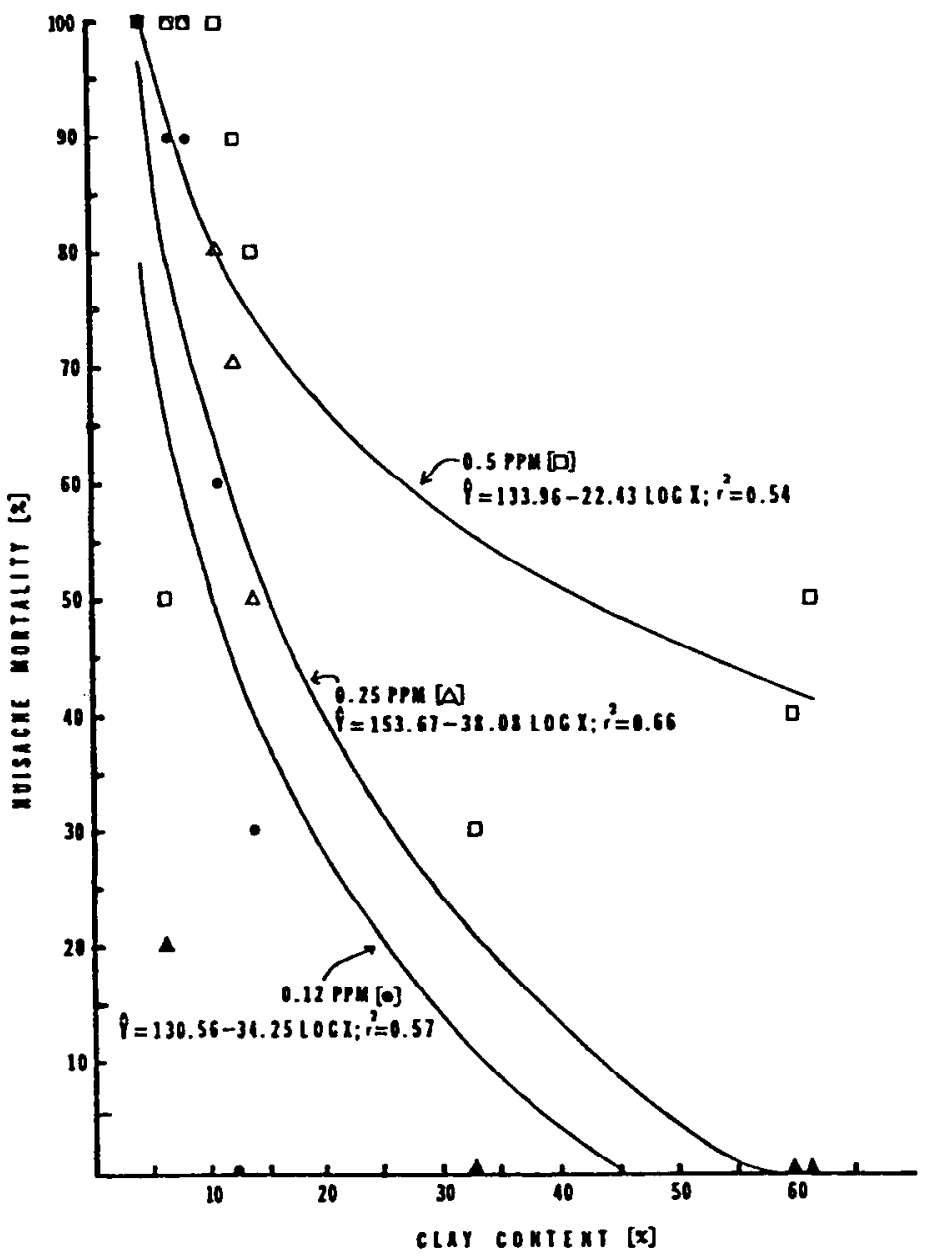

Fig. 2. Variation in percentage mortality of huisache populations growing in soils of various clay contents at 287 days after application of several rates (ppmw) of tebuthiuron in a greenhouse.

Mortensen, J.L. 1965. Partial extraction of organic matter. In: C.A. Black (Ed.). Methods of Soil Analysis (Part Il). Amer. Soc. Agron., Madison, Wis. 1401-1407.

Pettit, R., and V. Jones. 1978. Two experimental herbicides for oak control. Res. Highlights, Noxious Brush and Weed Control, Texas Tech Univ., Lubbock. 9:35-36.

Scifres, C.J. 1980. Brush management. Principles and practices for Texas and the southwest. Texas A\&M Univ. Press.

Scifres, C.J., J.L. Mutz, and W.T. Hamilton. 1979. Control of mixed brush with tebuthiuron. J. Range Manage. 32:155-158.

Scifres, C.J., J.W. Stuth, and R.W. Bovey. 1981. Control of oaks (Quercus spp.) and associated woody species on rangeland with tebuthiuron. Weed Sci. 29:270-274.

Sheets, T.J. 1958. The comparative toxicities of four phenylurea herbicides in several soil types. Weeds 6:413-424.

Sherburne, H.R., and V.H. Freed. 1954. Adsorption of 3-(p-chlorophenyl)-1,1-dimethylurea as a function of soil constituents. J. Agr. Chem. 2:937-939.

Ueckert, D.N., P.W. Jacoby, Jr., and F.S. Hartmann. 1982. Tarbush and forage response to selected pelleted herbicides in the western Edwards Plateau. Texas Agr. Exp. Sta. Bull. 1393.

Upchurch, R.P. 1958. The influence of soil factors on the phytotoxicity and plant selectivity of diuron. Weeds 6:161-171. 